\title{
8
}

\section{Institutional Design for China's Innovation System: Implications for Intellectual Property Rights}

\author{
Joseph E. Stiglitz ${ }^{1}$
}

Thirty years ago, China began its march to a market economy "with Chinese characteristics." At the time, it was not clear what that meant. Even today, what this entails is the subject of debate and discussion. Various chapters in this book have focused on what it might involve for, for instance, the property rights regime.

This chapter focuses on a particular kind of property-intellectual propertyand its role as part of society's innovation system. A country's innovation system is the collection of institutions that promote innovation, providing incentives and finance and allocating resources among researchers and research projects. The innovation system is concerned with the production, import, and dissemination of ideas and knowledge throughout the economy and society, including the creation of new products and the improvement of production processes.

There are many components of an innovation system besides intellectual property rights. Much research — and especially basic research, the most foundationalgoes on within universities, think tanks, and government laboratories, typically financed by government, sometimes in partnership with the private sector, sometimes supported by foundations. It is important to recognize this, because (as we shall argue at greater length) often too much importance is ascribed to intellectual property.

The design of the innovation system is especially important for China today for several reasons. China has been engaged in transforming its economy, and part of that transformation entails becoming an innovative economy. One of China's main challenges is closing the knowledge gap that separates it from more advanced industrial countries. In spite of huge progress in many areas, that gap remains large. Total factor productivity-output per unit of input-is markedly lower in China, reflected in lower per capita GDP. ${ }^{2}$

Two of the central elements in the Eleventh Five-Year Plan, which took effect in 2006, were creating a more innovative economy and the design of institutions for China's distinctive market economy, including those critical for the innovation economy. 
China has always learned from the experiences of other countries, both successes and failures. The Western innovation system has been highly productive, but while the strengths of that system should be obvious, so too should its limits. Research in some areas is, for instance, highly distorted. Consider pharmaceuticals. The system appears highly inefficient, with expenditures on marketing/ advertising exceeding that on research; more research is directed at lifestyle improvements (growing hair) than at attacking diseases; research is directed more at addressing diseases of the rich (who can afford expensive medicines) than those of the poor; and much research is directed at "me-too drugs," drugs similar to ones that are already patented, and at "evergreening"-making sure that there is just enough improvement in a drug to extend the life of the patent. The system is costly, with expenditures on patent lawyers rivaling expenditures on research. And, as we shall see, while the patent system leads to short-run inefficiencies (such as monopolies), there is increasing doubt whether, as currently designed, it actually promotes innovation.

As China assesses what kind of intellectual property regime and innovation system is appropriate for it today, it needs to recognize that there are many different intellectual property rights regimes and innovation systems; what works well in one country, may not work well in another. China's circumstances are markedly different from that of the United States and Western Europe. There are at least three distinct aspects of China's current situation:

(i) China is currently a net absorber of knowledge, a feature that China shares with most other developing countries.

(ii) Unlike most developing countries, however, China will be moving quickly into the production of new, patentable ideas, from which it can earn rents abroad. Even if the patent system is less central in motivating research within the country, it can be used as an important generator of revenues. There is also a defensive posture: it can facilitate better bargaining outcomes. When a foreign firm has the patent on a standard, it can extract considerable rents. China, with its own technology, can institute its own standard, forcing others to pay it. It may be desirable to do so, even if China's standard may not be as good as the alternative, at least in some dimensions. And the knowledge that China can do this enhances its ability to bargain better terms.

(iii) While most innovation in the West has focused on saving labor, China has an abundance of labor. Little of the innovation in the West has focused on saving natural resources. Doing so, and protecting the environment, will (and should be) a central focus of its research.

The choices that China makes over the next few years may be critical in determining its economic evolution and achieving broader social and economic goals. The wrong intellectual property rights (IPR) regime could make it more difficult to close the knowledge gap, impede China's emergence as an innovation leader, and hamper access to lifesaving drugs. The right IPR system could facilitate China's influence in developing countries, as it provides low-cost generic medicines.

One of the central messages of this chapter is that the dictums emanating from Western governments-that China should imitate their intellectual property 
regimes and that the stronger the intellectual property regime, the better-should, at best, be viewed with skepticism. To a large extent, they represent the perspectives of certain special interests (such as the pharmaceutical and entertainment industries) that benefit from America's current intellectual property regime. Those with less of a vested interest have not only pointed out the short-run inefficiencies associated with this but also argue that it may slow down the overall progress of innovation.

When I served on President Clinton's Council of Economic Advisers, we provided our assessment of the TRIPS agreement, the intellectual property provisions of the 1994 WTO Uruguay Round agreement, which sought to impose an American-style intellectual property regime on developing countries. Both we and the Office of Science and Technology Policy within the White House basically opposed TRIPS, believing that it was bad for American science, global science, and the economies of the US and developing countries alike. Many of America's own innovative firms are trying to change its IPR regime, which is designed not to maximize innovation but rents from those who have had the good luck receiving a patent (and the two are not the same).

I believed then, and I believe even more so now, that there was a need for reform in the US IPR regime and that it would be wrong to impose such a flawed regime on others. As badly designed as America's IPR regime is for America, it is even worse suited for China; but even if America's IPR regime were ideal for the US, that does not mean that it would be ideal for others. What China needs is a development-oriented intellectual property regime, designed specifically for China's stage of development.

\section{COMMON THEMES}

This chapter is of interest both because of the central role that the institutional structure of China's innovation system will play in China's future and also because an analysis of the innovation system illustrates several of the general and central themes of this book.

Institutional transplants don't work. Institutional structures that are appropriate for one country may not be the best for another. One-size-fits-all prescriptions don't work in general, ${ }^{3}$ but this is one area where they may work particularly badly. Institutional structures have to be sensitive to differences in objectives-a difference to which we have already alluded. Any particular institution (treating IPR, for the moment, as an institution) also must fit in with a broader set of institutional arrangements, which inevitably differ from country to country, shaped by circumstances and history.

Even the World Intellectual Property Organization (WIPO)—an organization that in the past seemed to act as if the stronger the intellectual property, the better-has recognized that the intellectual property regime that is appropriate for the developed countries is not appropriate for developing countries. On October 4, 2004 the General Assembly of WIPO decided to advance an IPR agenda that was, for the first time, explicitly developmentally oriented. The adoption of the Brazilian and Argentinean proposal for a development agenda 
was a major step forward for several reasons. First, it recognized that intellectual property "is not an end in itself." "promote creative intellectual activity" and "the transfer of technology to developing countries." The new development agenda calls for ascertaining how different intellectual property regimes affect developing countries. The set of provisions appropriate for the advanced industrial countries are different from those appropriate for the least developed, and both are different from those that would work best for emerging markets, such as China. It is not just a question of "strong" or "weak" intellectual property rights, but rather the design of the whole intellectual property regime, with its myriad of provisions, that matters.

Institutional details matter. Key parts of any country's intellectual property regime entail large elements of interpretation and judgment and are typically defined as much by courts as by legislation. For instance, there is general agreement that patents should only be granted for true innovations, attaining some standard of novelty. But what should be the minimal standard of novelty? Conflicts around such issues between developing and developed countries (and within developed countries) already abound: the US is willing to grant patents for traditional knowledge (such as traditional medicinal uses of certain plants), which developing countries argue should not be patentable. The patents on neem oil, basmati rice, and the medicinal uses of turmeric have been widely criticized by developing countries. ${ }^{5}$ India refused to grant a patent for a time release version of a drug whose patent was about to expire. Opponents of the granting of the patent (rightfully, in my view) claimed that this innovation was obvious, significantly so that it did not deserve patent protection; the objective of the "innovation" was simply to extend the patent life of an existing drug.

Rights and restrictions. We have noted (Chapter 1) that all property rights come with restrictions; they are never unfettered. In the case of intellectual property rights, there are restrictions associated both with abuses-they cannot (or should not) be used to unduly restrict competition - and also with public uses-compulsory licenses can and have played an important role in ensuring access to knowledge when it is deemed central for the public interest. Different countries may come to different judgments about which abuses are unacceptable or which public interests are essential.

The central point is that intellectual property rights-like other institutions-are social constructions that need to be adapted to the circumstances, history, and objectives of each country. In evaluating alternative innovation systems, there are several criteria. The ultimate objective is the well-being of society. That, in turn, is affected by the pace and direction of innovation and the efficiency with which resources devoted to research are used. But the innovation system does not exist in isolation. It can, for instance, affect the competitiveness and efficiency of the entire economy, the extent of inequality in society, and the health of its citizens. It can even have large budgetary consequences, as in the United States, as government pays pharmaceutical companies large amounts for drugs, the production costs of which are but a fraction of what the government pays-in some cases, even for drugs based largely on government-financed research. The US may be able to afford such largesse (though that is increasingly being questioned); for a developing country like China, the opportunity cost of these funds is enormous-the 
money could have been better spent promoting education or innovation-and there are even better ways to spend the government's health budget.

This chapter will provide an outline of an innovation system, and its associated intellectual property regime, that may be suited for China's circumstances. The next section explains the basic economics of knowledge, arguing that knowledge is different from ordinary goods, such as steel, where markets can be relied upon. Intellectual property rights introduce static inefficiencies into the economy, but unless IPR regimes are well designed, these inefficiencies can be compounded by slower innovation and distortions in the allocation of scarce research resources, contrary to the claims of its advocates. The following section views IPR as part of a broader innovation system and describes what such a regime might look likeincluding the advantages and disadvantages of various ways of financing and providing incentives for research.

Following the earlier observation that details matter, the next section examines a number of the critical details in an IPR regime. The final two sections focus on the design of intellectual property regimes that promote development, and on the challenge posed by the creation of a global intellectual property regime.

\section{KNOWLEDGE AS A PUBLIC GOOD: INCENTIVES AND INEFFICIENCIES}

Knowledge does not come free; resources must be expended on its production and dissemination. It has long been recognized that some form of intellectual property protection can play an important role in providing incentives for innovators, writers, and other creative artists. But intellectual property rights are different from other forms of property rights. While they provide an incentive to innovate, they cause an economic distortion by inefficiently restricting the use of knowledge and creating a (temporary) monopoly power. Ordinarily, property rights are argued for as a means of achieving economic efficiency. ${ }^{6}$ Intellectual property rights, by contrast, result in a static inefficiency, justified (in the eyes of its advocates) by dynamic benefits.

The analysis of IPR thus consists of (i) assessing the nature and magnitude of the static inefficiencies to which it gives rise; (ii) evaluating whether it does in fact give rise to dynamic benefits; (iii) determining whether there are ways of designing IPR regimes that reduce the static costs and increase the dynamic benefits; and (iv) assessing whether there are alternative ways of financing and creating incentives for innovation, without the drawbacks of IPR.

The central arguments of this chapter is that (i) the static costs are significant; (ii) the dynamic benefits are less than its advocates claim; (iii) there are reforms to the intellectual property regime-institutional structures that are markedly different from those that characterize the US IPR regime-that would enhance the benefits and reduce the costs; and (iv) there are alternatives to the IPR regime that, in many contexts, are superior. The IPR regime should be viewed as part of a portfolio of arrangements for financing and rewarding innovation-a portfolio that 
in the US and some other countries is currently unbalanced, with too much weight placed on a poorly designed IPR regime.

\section{Basic economics: knowledge as a public good}

The analysis of the economics of research begins with the observation that knowledge is a public good-at least in the sense that there is no cost to an additional individual having that knowledge. ${ }^{7}$ Economists refer to this as nonrivalrous consumption. ${ }^{8}$ If I eat a candy bar, you cannot eat it; only one of us can consume it. If I know something, you can know it too. To deny you that knowledge, or the right to use that knowledge, gives rise to an inefficiency. Intellectual property is based on such an exclusion. In fact, knowledge is a global public good, that is, it is of potential benefit to anyone in the world. There is a global social cost in depriving anyone in the world the right to use available knowledge. ${ }^{9}$

These global social costs are high: They include the value of the lives of the thousands of people who die because they cannot afford AIDS drugs at the high/ monopoly prices that the drug companies might charge. Standards of living in the developing world are kept low, because those in developing countries confront barriers to accessing enduring knowledge that would improve productivity and standards of living.

There is another cost: intellectual property rights can give rise to monopoly power. Monopolies interfere with the efficiency of the economy and lead to lower levels of production and higher prices than would prevail with competition. At one time, it was thought that this cost was low, for the monopoly power would only be temporary. In Schumpeterian competition, competition in the market is replaced by competition for the market. And there was even a dynamic benefit: competition for the market led to faster research. ${ }^{10}$ Some went even further, arguing that even if there was a single firm in the market, potential competition would suffice to ensure efficiency. Each of these assumptions was shown to be wrong, so long as there are any sunk costs (Stiglitz 1988). Potential competition did not suffice to ensure efficiency, and besides, patents preclude potential competition. Incumbent monopolists could, and would, extend their monopoly power, which often was far from temporary. And given the sunk-cost nature of research expenditures, an incumbent could deter competitive entry with only a limited amount of research, so that innovation with monopoly could be substantially lower than with more competition. ${ }^{11}$

\section{Basic economics of innovation: discrepancies between social and private returns and distorted incentives}

There is a second key aspect of the economics of innovation: there are marked discrepancies between social and private returns within any patent system, though the magnitude of the discrepancy will be larger with poorly designed IPR regimes. In a well-functioning market economy, there is normally a close congruence 
between marginal private and social returns. But this is not true in the case of returns generated by intellectual property rights.

The social return to an individual's research is not the invention or innovation that might be produced; rather, it is the fact that the invention or innovation was produced earlier than it otherwise would have been. The patent system is a winner-takes-all system: if there are a large number involved in a patent race, the winner gets the entire return; the losers typically get nothing. But if the winner had not done his research, the invention would have been discovered by one of the other researchers, only slightly later. It is not even in general the case that the average compensation under the patent system corresponds to what compensation would have been, had we been able to base compensation on marginal contribution.

Particularly if the patent is broad, or if monopoly power in one area can be leveraged into monopoly power in another, the private return may substantially exceed the social return. Many patents (and the research behind them) are focused not so much in producing a product that is better, valued more by consumers, or cheaper, but rather in enhancing market power, e.g., by extending market dominance. Patents can, and often are, used as a barrier to entry. The social return to such innovations can even be negative. At the same time, patents sometimes give rise to research of limited social value, as others try to innovate around a patent. The social return on a me-too invention (designed simply to circumvent an existing patent) is zero. ${ }^{12}$ Similarly, there may be relatively low-or even negative-social benefits to allowing patents of traditional knowledge. Such patents obviously don't generate new knowledge, but they may impede the use of knowledge.

In short, the patent system not only does not reward inventors on the basis of their marginal contributions, but sets up a distorted set of incentives for innovations, where inventive activity is directed first at creating market power, and then, by others, at overcoming the artificially created market power. At the same time, the fact that innovations give rise to spillovers and externalities, which are not captured even by strong intellectual property rights, suggests that in many circumstances, the private returns are less than social returns.

The lesson that emerges from this discussion is that, unlike other areas where markets can be relied on to produce efficient outcomes, this is not the case for research. Government has to play a role-indeed, even market advocates argue that government has an important role in creating an intellectual property regime. But a good intellectual property regime tries, on average, to align private and social returns, and to minimize the static costs and maximize the dynamic benefits. Sometimes, as we shall see, it is better to turn to other ways of providing incentives and financing research.

\section{Does IPR actually promote innovation?}

While the costs of IPR in terms of static inefficiency are unambiguous, the benefits, in terms of increased innovation, are ambiguous. A poorly designed intellectual property regime can actually lower the pace of innovation. In these cases, there is considerable social cost and little social benefit-dynamic or 
static - to the patent. The economy loses twice, both from dynamic and static inefficiency.

There are several reasons that strong IPR may impede innovation. The first we have already noted: the monopoly power to which intellectual property rights give rise may actually lead to less innovation, because monopolies may have insufficient incentives to innovate. ${ }^{13}$ Moreover, monopolists have incentives-and the ability-to suppress the innovation efforts of others, which critics of Microsoft, for instance, have argued that its policies have done. ${ }^{14}$ Second, because research is the most important input into the product of knowledge, by increasing the "price" of knowledge, the pace of knowledge production may be reduced. ${ }^{15}$ Even in the United States, there is considerable concern that, for instance, patenting the human genome may impede follow-on research. ${ }^{16}$

The value of many patents arises in part from "enclosing the commons," creating even more severe problems. ${ }^{17}$ Often the patent covers knowledge that already exists. While in principle, patents are supposed to be granted only for new knowledge, defining new knowledge is not always easy. The criticism of patenting traditional knowledge is that the knowledge covered was previously known. It may, of course, not be known to the patent examiner, and it may not have been published. Indeed, it may not be easy to publish knowledge that is so widely known as to be considered "common knowledge."

Moreover, increasingly innovators face the problem of the "patent thicket," the risk that any innovation "trespasses" on others' intellectual property rights, or at least so they might claim. The most famous recent case involved BlackBerry, whose maker, Research in Motion, was forced to pay hundreds of millions of dollars, under the threat of being forced to shut down, for trespassing on patents, most of which were ultimately declared invalid.

Finally, no matter how well designed the patent law, intellectual property inevitably involves ambiguity — not only over whether there is a legitimate patent (e.g., has the novelty standard been met?), but over the scope of the patent. While it is generally relatively easy to define ownership rights over and boundaries of physical property, this is not so for intellectual property. Did or should George Baldwin Selden's original patent for a four-wheel self-propelled vehicle include all such vehicles, or only the one he sketched out? ${ }^{18}$ A potential producer may be uncertain about whom he needs to pay to have the right to produce. He may pay party A, only to find out that party B also has a claim. Patent conflict can impede, and in the past has impeded innovation. Conflicting airplane patents held by the Wright Brothers and Curtis impeded the development of the airplane until World War I, when the government forced the pooling of patents.

The resources devoted to litigation are part of the transaction costs associated with running an intellectual property regime. Financial resources devoted to these costs - which can be considerable-could have been used more productively on research itself. At the very least, the potential of such conflicts adds uncertainty to the innovation process and discourages investment in research.

There are other costs to the patent system. Because rewards are based on who wins the "race," market participants have every incentive not to help others and to hinder competitors. The basic research community rests on principles of openness, transparency, and sharing knowledge; patents lead to secrecy and closed communities-which are antithetical to the progress of science. ${ }^{19}$ 


\section{Balancing static inefficiencies and dynamic gains}

Advocates of intellectual property rights have recognized IPR's static costs, but they claim that they are more than offset by the social benefits from the resulting induced innovation. A balanced intellectual property regime weighs static and other costs against dynamic benefits. "Balance" must affect every feature of the intellectual property regime, from what can be patented, to the life of the patent, to the breadth of the patent, ${ }^{20}$ to the standard of novelty invoked in granting a patent. An unbalanced intellectual property regime-say one with an excessively long patent life-leads to overall inefficiency. The increases in incentives to innovate, from the increased present discounted value of profits from the extension of monopoly power, say from twenty to eighty years, are almost surely of less importance than the present discounted value of inefficiencies to which such an extension of patent life gives rise.

Too often, the advocates of IPR underestimate static losses, overestimate dynamic benefits, and disregard "balance." Even as they note that it may create monopoly power, they emphasize its temporary nature, ignoring the research (noted above) showing that such power can persist and that even attempts to maintain monopoly distorts resource allocations. In the discussions leading to the TRIPS agreement, this careful balancing was totally missing. The argument was essentially: the stronger the intellectual property rights, the better. This is wrong.

\section{IPR AND CHINA'S NATIONAL INNOVATION SYSTEM ${ }^{21}$}

So far, our discussion has focused on the potential disadvantages of the IPR system - that it inevitably gives rise to static inefficiencies, and excessively strong, poorly designed property rights may actually impede innovation and growth.

This brings us naturally to the critical question: are there better alternatives to IPR for producing and financing knowledge than the system, with its attendant distortions, of incentives through patents and copyrights?

Advocates of stronger intellectual property rights give the impression that they are essential for innovation. A moment's reflection should make it obvious that there are many alternative ways to finance and reward innovation. There are, for instance, other ways of appropriating returns from innovation (trade secrets, firstmover advantage) besides patents and copyrights, and in many areas these are highly effective. In fact, many of the most important advances in knowledge are not protected by intellectual property rights and were not motivated by monetary gains. The basic mathematic advances that provided the underpinnings of the computer are but one of a large number of examples. Mathematical theorems cannot (and, I would argue, should not) be patented.

There are other ways of financing and providing incentives for research. The US and other governments finance much of the basic research upon which pharmaceutical companies base their innovations. The Internet, which has spawned myriad innovations since the 1990s, was based on research that was supported, and largely conducted, by US and European governments. The fact 
that so much of the successful innovation in the United States has occurred in research parks adjacent to universities suggests that these firms are benefiting from knowledge produced in the universities; and university research is, by and large, funded by foundations, government, and university endowments-but not motivated by the search for profit.

More recently, the open-source movement in software has been an important source of innovation. While its original successes were in software, it is now demonstrating its effectiveness in other arenas, such as biotechnology. ${ }^{22}$

\section{Alternative ways of financing knowledge production}

We can think of IPR as a method of funding research—a highly distortionary method. Price exceeds marginal cost by a considerable amount, for a limited period of time, and the resulting monopoly profit not only provides the incentives, but also the resources for innovation. This gap between price and marginal cost can be thought of as a tax, part of the proceeds of which are used to finance research. In the last seventy-five years, there has been considerable research into the optimal way of raising ( $\operatorname{tax})$ revenues. There is no research suggesting that the "implicit" taxation of IPR (even if all the proceeds were devoted to R \& D) has any optimality properties. Its principal virtue is that it is a benefit tax, that is, only those who benefit from the innovation pay for it. But in most arenas, we do not employ benefit taxes, largely because the additional distortions associated with such taxes are generally not viewed as worth the slight gain in "equity." In the area of lifesaving drugs, such an argument is even more compelling, since typically those who need the drugs are already suffering from having a life-threatening disease. In the case of drugs, the "monopoly tax" is an inefficient way of funding research for yet another reason: a large fraction of the revenue does not reach its target-it is spent on marketing and advertising, rather than on research.

While within the United States the distortions in consumption and inequities associated with monopoly pricing as a basis of research-funding for medicines may be limited, because so much of the funding for health care is from third parties, and there may be accordingly little price elasticity, internationally this is not true. And even in the United States, there are large distortions arising out of rent-seeking -in the quest to garner monopolistic returns. But especially in developing countries, high prices effectively deny access to lifesaving drugs for large numbers of people. More generally, the in-effect benefit tax is regressive. A more equitable system of financing would be progressive and those more able to pay would pay more- and indeed a larger share of their income. Indeed, one can argue that in countries such as China where individuals have to pay a larger share of their drug costs, not charging prices above marginal cost for lifesaving drugs may be a desirable way to provide assistance to poorer people who have the misfortune of suffering from disease. Governments around the world now directly or indirectly pay for a large share of the cost of drugs. A system of direct payment for the underlying research combined with marginal cost pricing would make what is going on more transparent, would be a more equitable system of finance, and would lead to better resource allocations. 


\section{Production vs finance}

The issues of production and finance largely can be separated. Production can be undertaken privately or publicly; finance can be undertaken privately or publicly. At one extreme are government research laboratories-publicly financed research that is also publicly "produced." The IPR system is often described as the polar opposite, a private-sector solution combining private funding and private finance. But this description is misleading in two respects that we have already noted. First, much of the innovation is based on basic research that is publicly funded and often publicly produced or at least not produced by for-profit entities. And second, in the case of both health and defense, even the seemingly "private" funding under an IPR regime is really public funding, since all defense expenditures are from the public purse and since the government provides most of the funding for health care expenditures in most countries. Even in the most market-oriented country, the United States, much of the funding comes from government: the National Institutes of Health represent publicly financed and publicly produced research; and government spending on health care, both through its program for poor people, Medicaid, and its program for elderly people, Medicare, represents a large share of total health care spending. ${ }^{23}$

\section{Prizes}

The prize system represents one alternative to the patent system for providing incentives for research. This entails giving a prize to whomever comes up with an innovation, or at least those innovations that meet announced objectives. For instance, the person who finds a cure or a vaccine for AIDS or malaria would get a big prize. Someone who comes up with a drug with slightly different side effects than existing drugs (but which is otherwise no more effective) might get a small prize. The size of the prize is calibrated by the magnitude of the contribution.

The idea is an old one. The UK's Royal Society for the Encouragement of Arts, Manufactures, and Commerce has been advocating and using prizes to incentivize the development of needed technologies for more than a century. For instance, an alternative was needed for chimney sweeps, those small, underfed boys who used to be sent down chimneys. It was not good for their health, but not cleaning chimneys meant increasing the risk of fire, with serious consequences. So the Royal Society offered a prize to anybody who invented a mechanical way of cleaning chimneys. The prize provided an incentive-and it worked. A patent system might also have motivated the development of a mechanical device (though it did not), but if it had, there would have been a problem: the owner of the patent would have wanted to maximize the return on his innovation by charging a high fee for its use. That would mean that only rich families could have afforded to use the mechanical device, and young boys' lives would have continued to be put at risk. With the prize system, everyone could benefit from this socially important innovation.

The current patent system is, of course, similar to a prize system, but it is an inefficient one, because the "prize" is a grant of monopoly power, and with 
monopoly power there are incentives to restrict the use of the knowledge. One of the characteristics of a desirable innovation system is that the ideas and innovations, once developed, are widely used and disseminated; the patent system is designed to restrict the use of knowledge. With the prize system, the competitive market ensures efficient dissemination; giving licenses to a large number of people uses the force of competition to drive down the price and to increase the use of the knowledge. With both patents and prizes, market forces are used: one is the incentive of a monopoly to restrict knowledge and raise prices, the other is the force of competitive markets to drive down prices and extend the benefit of knowledge widely.

Moreover, the prize system has the advantage of creating fewer incentives to waste money on advertising and to engage in anticompetitive behaviors designed to enhance monopoly profits. Drug companies spend more on advertising and marketing than they do on research. These marketing expenditures are designed to reduce the elasticity of demand, which allows the owner of the patent to raise prices and increase monopoly profits. From a social point of view, these expenditures are dissipative.

The patent system also distorts the pattern of research: drug companies have insufficient incentives to develop medicines for the diseases that tend to afflict poor people, simply because there is no money in those drugs. One of the widely discussed ideas for addressing this problem is a guaranteed purchase fund, in which the World Bank or the Gates Foundation would guarantee one or two billion dollars to the person or people who develop a vaccine or cure for AIDS, malaria, or some other disease afflicting the developing world for the purchase of the drug. In effect, there would be a certain market. The guarantee of one or two billion dollars for the purchase of the drug would act as a prize, and a sufficiently large guarantee would provide a clear motivation for research. These guaranteed purchase funds, however, would still maintain the inefficiency of the monopoly patent system, unless there was an accompanying commitment that would make the patent accessible to all at reasonable royalties for purchases beyond the guarantee. The discoverer receives his "prize"-the monopoly profits-by charging monopoly prices. The poor, who get the drugs through the guaranteed purchase fund do not, of course, pay the monopoly price. But the funds are limited and when they are used up, without such a commitment, a government that wants to provide to its citizens, say, the malaria medicine that has been bought through the guarantee purchase fund, will have to pay the full monopoly price.

Money spent purchasing this drug at the monopoly price is money that cannot be spent on the country's other health needs. It may be far better to use the money for the guarantee purchase fund in a way which spurs competition in the provision of the drug, to offer a prize, or to buy the patent, and to allow anyone willing to pay a limited licensing fee to produce it.

In areas where there are well-defined needs (such as the need to develop a malaria vaccine) both the prize system and the patent system can provide comparable incentives to undertake research. Both have the advantage over government-funded research that no one has to pick who should undertake the research: there is a process of self-selection; those who think that they have the best prospects of succeeding (and are able to finance the research and willing to bear the risk) undertake the project. The prize system uses the force of competitive 
markets to ensure the widespread dissemination of the benefits of the innovation; the patent system uses monopoly power, restricting the usage, and often distorting the markets in other ways.

\section{A PORTFOLIO APPROACH TO INNOVATION}

Intellectual property rights should be part of an innovation system that also includes prizes and government-supported research and grants (which are probably the most important component of the innovation system in supporting basic research). Each of these has its strengths and weaknesses. Table 8.1 provides a chart of some of the attributes of these three alternatives.

As we noted, any innovation system has to solve the problems of finance, selection (who gets research money), and incentives. There are, in addition, problems of coordination of research efforts. How these tasks are solved will affect the efficiency of the system-including the uncertainty and transaction costs facing market participants.

Every country should have a portfolio of instruments, but in our view, too much weight has been assigned to patents in the current portfolio in the US. As China thinks about its own innovation system, it has the opportunity to redress this imbalance, reducing the role of patents and increasing the role of prizes and government-sponsored research.

The first attribute listed is selection. One problem facing any innovation system is how to select those to engage in a research project. The advantage of both the patent and the prize system is that they are decentralized and based on self-selection. Those who think that they are the best researchers make the decision to undertake the research. They make the investment, risking their own money, in the belief that they have a good chance of winning the prize (the formal

Table 8.1. Comparing alternative systems

\begin{tabular}{|c|c|c|c|}
\hline \multirow[b]{2}{*}{ Attribute } & \multicolumn{3}{|c|}{ Innovation System } \\
\hline & Patent & Prize & $\begin{array}{l}\text { Government- } \\
\text { Funded Research }\end{array}$ \\
\hline \multirow[t]{2}{*}{ Selection } & $\begin{array}{l}\text { Decentralized, self- } \\
\text { selection; }\end{array}$ & Decentralized, self-selection; & Bureaucratic; \\
\hline & lacks coordination & lacks coordination & $\begin{array}{l}\text { more coordination } \\
\text { possible }\end{array}$ \\
\hline Finance (tax) & $\begin{array}{l}\text { Highly distortionary } \\
\text { and inequitable }\end{array}$ & $\begin{array}{l}\text { Can be less distortionary } \\
\text { and more equitable }\end{array}$ & Most efficient \\
\hline Risk & Litigation risk & Less risk & Least risk \\
\hline Innovation Incentives & Strong but distorted & $\begin{array}{l}\text { Strong, less distorted; } \\
\text { requires well-defined } \\
\text { objectives }\end{array}$ & $\begin{array}{l}\text { Strong } \\
\text { nonmonetary } \\
\text { incentives }\end{array}$ \\
\hline $\begin{array}{l}\text { Dissemination } \\
\text { Incentive }\end{array}$ & Limited-monopoly & $\begin{array}{l}\text { Strong_-competitive } \\
\text { markets }\end{array}$ & Strong \\
\hline Transaction Costs & High & Lower & Lower \\
\hline
\end{tabular}


prize or the prize of the patent). The prize and patent systems have this advantage over government-funded research, in which there is a group of peers (or bureaucrats) deciding on the best researcher. There is obviously also a concern about "capture" of the research-awarding process, e.g., by political or economic interests whose agendas may be separate or counter to the advancement of science and technology.

With respect to finance, the patent system is the worst of the three systems. It is highly distortionary and inequitable in the way in which funds to support research are raised-by charging monopoly prices, e.g., on the sick. By the same token, the transaction costs (especially those associated with litigation) and the distortions in the economic system are much higher with a patent system than with the other two.

Regarding the dissemination of knowledge and its efficient use, governmentfunded research is best (because knowledge is generally made freely available); the prize system is second (though there may be little difference compared to government-funded research if, after the prize is awarded, knowledge is made freely available or if, with government-funded research, the government charges a licensing fee); and the patent system is the worst, given that it relies on monopolization, which entails high prices and restricted usage. In short, under the prize and the government-funded research systems, knowledge, once acquired, is more efficiently used. These are among the key advantages of these alternatives.

There is a big difference in the nature of the risk faced by researchers operating in the three systems. One of the disadvantages of both the patent and the prize systems is the lack of coordination. From a societal point of view, there is a risk of excessive duplication. ${ }^{24}$ The lack of coordination increases the cost of doing research. One of the risks that each researcher faces is not knowing how many other people are engaged in that research. This increases the risk that someone else will make the discovery first, and thus get the patent or prize. Governmentfunded research can be more coordinated. The patent system imposes a second risk, that of costly litigation. Thus, with respect to risk, the patent system is the worst and the government-funded system is the best, because it has the advantages of paying for the input rather than the output. That is to say, a researcher gets money for his time and other resources spent doing the research, whereas in the prize and the patent systems researchers are rewarded only if their research is successful-and successful before their rivals.

One of the reasons that risk is important is that in equilibrium consumers have to pay for the risk borne by researchers. People and firms ${ }^{25}$ are risk-averse, and if they must bear risk, they have to be compensated for doing so. The patent system makes society bear the cost of that risk in an inefficient way. Under the government-financed research system, not only is risk lower, but it is shared by society in a more efficient way.

Innovation incentives are strong in the patent system, but they are distorted, whereas the prize system can provide equivalent incentives that are less distorted. (They are distorted, as we have noted, because there are incentives to engage in research to innovate around a patent and to spend money in ways that extend the effective life of the patent. These innovation distortions are in addition to the other market distortions, such as those associated with expenditures attempting to make demand curves less elastic.) 
On most accounts, the prize system dominates the patent system; but the prize system has one limitation: it does not work when the objective is not well defined. (There are, however, many areas, such as health, energy conservation, and carbon emissions reductions, in which there are well-defined objectives.) That is why the prize system will never replace the patent system. At the same time, in basic research - the foundation on which everything else is built-government-funded research will continue to remain at the core of the innovation system. No one has proposed otherwise: the costs of restricting the usage of knowledge associated with the patent system far outweigh any purported benefits. The debate today revolves only around applied research, which often entails translating the knowledge acquired in basic research into applications.

\section{LEGAL AND POLICY FRAMEWORKS}

The first part of this chapter outlined some of the economic principles foundational to a balanced and development-oriented intellectual property regime. Such principles get translated into action through legal and policy frameworks. In designing these frameworks, details matter. Unfortunately, many of the current frameworks do not reflect the kind of balance for which we have advocated, and may actually hinder development and innovation. The problem arises partly from a failure to understand the economics, partly from a failure to understand property rights, and partly because the agenda of those pushing for stronger intellectual property rights is concerned more with rent-seeking than with efficiency and equity.

The following discussion focuses mostly on details concerning the IPR regime. As the conclusion of the preceding section emphasized, IPR should be viewed as part of an innovation system, and there are many government actions besides the IPR legal framework that affect the structure of the entire system. These include government support for research and teaching (including research universities) and the creation of a prize system for needed innovations in areas such as energy efficiency and health. Earlier, we noted the open-source model as an alternative to IPR. Some governments have actively promoted open-source software by, for example, requiring all government computers to have only open-source software. There are occasions in which the open-source legal framework comes into conflict with the closed IPR framework, and where the two conflict, it is important to resolve in favor of open source.

There are also strong arguments for a publicly funded and managed system of pharmaceutical testing, a key component of the current innovation system for drugs (Jayadev and Stiglitz, 2009, 2010). In the current system, drug companies test their own drugs, an arrangement fraught with expensive, distortionary conflicts of interest.

Many details of an IPR regime are critical: what can be patented, the standards used for granting patents, the length and breadth of the patent, restrictions on the patent, how the patent is enforced, and rules governing the granting of the patent. In each dimension, there are complex trade-offs, e.g., between providing incentives for innovation on the one hand and introducing inefficiencies in the 
dissemination of knowledge and impeding follow-on innovations on the other. One of the reasons that there is a broad consensus against patenting mathematical theorems or other insights from basic research is that the disadvantages of patenting far exceed the advantages. Other patents, such as those for business processes, impose other costs, e.g., in terms of litigation risks.

Recent changes in IPR regimes have not always carefully balanced costs and benefits. The extension of the life of copyrights probably imposed more costs than any benefits from improved incentives. With weak standards of "novelty" and "obviousness" patent owners can "evergreen" their patent, thereby extending its life. There is a legitimate debate about the optimal length of the life of a patent ${ }^{26}$ - but such indirect ways of extending it almost surely have greater costs than any associated innovative benefits. The costs can be particularly high in the case of drugs in developing countries. ${ }^{27}$ There have been some excessively broad patents (as we noted earlier in the context of the original US automobile patent); the greater the breadth, obviously, the greater the value of the patent, but the greater the impediments for follow-on inventors. China should be particularly wary of broad patents.

Other details of the IPR regime can reduce the costs relatives to the benefits. Historically, to get a patent, knowledge had to be disclosed, which meant, in principle, that others could make use of that knowledge for their research. Patent rights can be viewed as an exchange, where the "public" grants a temporary monopoly right, circumscribed, in return for the revelation of information. More recently, some in the software industry have been arguing for stronger intellectual property rights without disclosure. China should insist on strong disclosure requirements. In the end, some may choose not to seek intellectual property protection, preferring to rely on trade secrecy.

The following sections focus on a set of key issues in the design of an IPR system.

\section{What can be patented}

Only certain things can be patented. The applicant is supposed to demonstrate, for instance, a certain standard of novelty. Even then, theorems cannot be patented. Some countries have restricted the granting of patents to processes for producing chemicals, not to the molecules themselves. An American court recently rejected the right to patent certain genes (that rejection was overturned shortly before this book went to press, a decision which is itself under appeal at the time of writing) ${ }^{28}$ This is a position taken by many other countries. America's business process patents have been widely criticized as extending the reach of patents too far.

\section{Breadth of property rights}

A common misperception is that, once a patent is granted, the grantee has the right to do anything with it during its lifetime, an uncircumscribed ability to exercise monopoly rights. Property rights do not in general, and should not, give the owners of property uncircumscribed rights, as we have emphasized 
throughout this book, and this is especially true for intellectual property rights. IPRs are not an end in themselves; they are a social construction, a means to an end-to promote societal well-being-which is accomplished through careful definition and design.

Examples in which public interest concerns circumscribe ordinary property rights abound; the general principle is that I cannot do things with my property that might adversely affect others. This provides, for instance, a justification for zoning. In these cases, there is a balancing of public interest and private rights.

US patent law illustrates these issues by excepting patent protection for government use. Under 28 USC 1498, the government is authorized to use any patent or copyright, which can be extended to any contractor, subcontractor, or employee working for the government. While there is extensive debate about the justification for this, the view taken by the United States Court of Federal Claims in the 1990s is telling: it recognized that the granting of a patent was a limited grant- just as it was limited in time, so too it was limited in use. Government use represents a power reserved to the government when it initially grants the patent: " "... the government cannot 'take' what it already possesses, the government [has] the absolute power to take a compulsory, nonexclusive license to a patented invention at will." 29 While other courts have challenged this interpretation, the Court of Federal Claims decisions make clear that reasonable people, even in advanced industrial countries, balancing interests and looking at the costs and benefits of stronger intellectual property rights, have come to the conclusion that these rights should be heavily circumscribed.

The question, accordingly, is not whether intellectual property rights need to be circumscribed to advance broader social objectives, but how much, and in what manner. The answers to this question for China are not necessarily the same as for the US or other advanced industrial countries.

\section{Curtailing abuses of market power through limitations on intellectual property rights}

For instance, intellectual property rights, by definition, create a monopoly power over the use of knowledge; but this is not a license for monopoly abuse. But what is meant by an abuse of monopoly power? And what should be the appropriate remedy? There is a broad consensus that Microsoft overstepped the boundaries by leveraging its market power over operating systems into other arenas. But while both American and European antitrust authorities have concurred on this, they have proposed different remedies, perhaps partly based on differences in judgments about the "balancing" of static and dynamic effects.

One of the responses to abusive, anticompetitive practices has been to restrict the use of patents, effectively insisting on compulsory licensing, sometimes through forming patent pools. In the consent decree in the case of the antitrust action against AT\&T in the 1950s, AT\&T had to make its patents available to anybody wanting to use them. ${ }^{30}$

Another proposed reform that has gained favor among some academics is limiting the life of intellectual property protection as a way of limiting abuses, 
increasing market competitiveness, and spurring innovation. If Microsoft's operating system had only a three-year protection, then it would be spurred to make significant improvements in each subsequent release. ${ }^{31}$

Again, what is clear is that there is no unanimity even among the advanced industrial countries on what appropriate balancing entails. China (and many other emerging markets and developing countries) should be particularly wary of monopolization; in certain sectors, because markets are less perfect, the threat of monopolization is greater. Monopolies, once created, tend to persist.

\section{Compulsory licenses}

Beside the restrictions arising from the threat of excessive monopolization, the two most important instances in which patent rights have been circumscribed have been when there is a threat to public health or in response to global warming. The 1992 Rio Agreement created a framework for addressing problems of climate change by providing for compulsory licenses for obtaining access to technology related to mitigation of emissions. The 1994 TRIPS agreement provided for compulsory licenses for lifesaving medicines.

\section{Rule of reason versus per se}

A key question in defining an intellectual property regime concerns presumptions. In standard antitrust policy, there are some areas in which per se rules applyprice-fixing is per se illegal. In other areas, the courts are asked to engage in a rule of reason, to balance competitive losses against any efficiency gains that might result from a vertical restraint.

While it may eventually be possible to devise simple rules for judging when, for instance, a compulsory license should be granted, intellectual property rights, especially in developing countries, are at an early stage of development. Simplicity—and the limited capacity of developing countries to engage in expensive litigatingargues that there should be strong presumptions in favor of limiting intellectual property rights when there is an apparent health, competition, or developmental objective. That is, the burden of proof should be placed on the original holder of the patent that there is not a legitimate health, competition, or developmental objective. For instance, in granting pharmaceutical patents, China should reserve the right to grant a compulsory license for any lifesaving or life-extending drug. To be exempt from this provision, the patent applicant would have to state that the patent does not cover any such medicinal use; and if subsequently such a use were established, the government would have the right to issue a compulsory license, limited, of course, to sales for such usages.

\section{The process of granting and enforcing patents}

We have argued that institutional details matter. Nowhere is that more evident than in the way that patents are granted and enforced. Different countries have 
approached these issues in different ways, and China should learn from these experiences, as well as from proposals that have been made to remedy the weaknesses in current prevailing practices. In Europe, there is a process of opposition: those who believe the patent should not be granted have an opportunity to express their views to the patent office before a patent is granted. There is no such provision in the US, exacerbating the bias toward excessive patenting that arises from the very structure of the patent system. Patents, as we have noted, privatize knowledge; but challenging a patent converts what is a private good into a public good. Thus challenging is itself a public good and, as in other arenas, the private sector will underinvest in the provision of this public good.

Once granted, the owner of the patent can exclude others from using his intellectual property until the patent is overturned. This has become a source of special concern, given the large number of bad patents-patents which should not have been issued, some of which are eventually overturned. Those who have such patents can impose extortionary demands on those who wish to make use of their patents. These "patent owners" can even insist that those to whom they grant license not sue-eliminating a major source of challenge to patents.

There are alternatives. For instance, under the "liability system," those who use another's intellectual property have to pay compensation, but the owner of the intellectual property cannot exclude someone from using the property. For an emerging market such as China, access to knowledge is essential for its future growth. Intellectual property cannot be used as an impediment to its development. The liability system (in effect, granting a compulsory license at fair compensation for the use of knowledge) is one way of preventing this from happening. Even more modest reforms, such as allowing the use of intellectual property so long as there is a challenge (with appropriate compensation paid if the patent is upheld) would be preferable to the existing system. ${ }^{32}$

\section{De jure and de facto fairness}

Legal systems often look fair on paper: everyone has a right to a day in court. In practice, obtaining justice is expensive, and those who cannot pay often cannot get it. That is why societies increasingly provide legal aid to those who cannot afford it. While there are still enormous imbalances, the system is fairer than it otherwise would be. In the West, because the patent system has become enormously expensive, it serves as an barrier to entry and is unfair to small firms. They already face disadvantages in obtaining finance for research; but under the patent system, they face further costs in attempting to get a patent. Worse still, when they have a successful product, they face the risk of being sued by a well-funded large enterprise for some patent infringement. And if there is no public enforcement of patent infringement, the well-funded enterprise can simply infringe on the patent of a smaller firm, knowing that in the legal battle that ensues, it is likely to prevail simply because of its greater resources.

China, if it wants to create a dynamic, innovative economy within a harmonious society, must ensure that there is de facto as well as de jure justice. Part of this must entail creating a legal system that does not give undue advantage to rich 
corporations and providing economic assistance to small and medium-sized enterprises in obtaining and enforcing patents.

This section has discussed an array of institutional details that are central to determining how the patent system works and whether it achieves the right balance between providing incentives and enabling new research versus the inherent costs associated with the restrictions on the use of knowledge.

\section{TOWARDS AN INTELLECTUAL PROPERTY REGIME THAT PROMOTES DEVELOPMENT}

For China, every issue that is up for discussion-from what is patentable, to the scope of the patent, to the novelty standard, to the limitations of intellectual property rights, to when governments have the right to grant compulsory licenses and on what terms - needs to be addressed from the perspective of development, in order to create a dynamic, innovative, competitive economy with a healthy population. Focusing on the developmental consequences of intellectual property provides a new lens through which to appraise each of these aspects of the intellectual property regime. The fact that intellectual property requires balancing a variety of concerns implies that one country's appropriate intellectual property regime may be different from that of another.

For instance, a development-oriented intellectual property regime might well recognize the right to grant a compulsory license when doing so promotes development, e.g., when it enables the country to reduce the technology gap that separates it from the more advanced industrial countries. For China, as it strives to create an innovation economy, to improve the health of its citizens, and to address the myriad of environmental challenges that it confronts, these issues are of particular importance.

A development-oriented IPR agenda would pay attention to:

(i) The importance of ensuring effective competition. There is even greater risk of limitations in competition in developing countries, where markets are by definition smaller than in Europe and the United States, so that even greater weight should be given to the risks that patents pose in decreasing competition.

(ii) The importance of ensuring access to lifesaving medicines. With strong budgetary limitations on both the household and government levels, higher prices translate directly into loss of life. Moreover, money spent in purchasing expensive drugs is money that is not available for other purposes, such as promoting developing through investments in education, health, technology, or infrastructure.

(iii) The importance of ensuring the transfer of technology. Unless the gap between developed and less developed countries in technology and knowledge can be closed, there will be no successful development. What is required is not only access to products and technology, but also the ability to learn how to produce with more advanced technologies, which may not be feasible without compulsory licensing. 
(iv) The importance of ensuring protection of traditional knowledge, recognizing the special problems in establishing patents in this area and the dangers here of "fencing in the commons."

(v) The importance of protecting genetic resources. Much of the world's biodiversity resides in developing countries and emerging markets. These countries must have incentives to maintain their biodiversity. In doing so, they provide a global public good, which they are currently being asked to provide without receiving any compensation. Their desire to develop puts these resources at risk. Providing property rights in the genetic material that is derived from these sources can be an important part of a global framework for providing incentives for developing countries to protect their biodiversity.

This chapter has explained that intellectual property rights are one part of a country's innovation system and that in the design of IPR, there are complicated trade-offs, e.g., involving static and dynamic considerations. There is no single "best" IPR system. How these trade-offs are balanced does, and should, differ according to the circumstances of each country. We have called for "balance" in intellectual property rights, a balance that will differ among countries. But that means that we need an international system that allows each developing country to choose the IPR regime that is appropriate for its own circumstances.

A one-size-fits-all regime is, accordingly, inappropriate. While there may be some advantages from a harmonization of standards, there are also marked disadvantages. In the Commonwealth-IPD report on the Development Round, we called for a "conservative principle" - that common standards only be adopted where there are overwhelming gains, especially to developing countries. ${ }^{33}$ Inevitably, in bargaining over standards, developing countries would be put at a disadvantage, and this was especially so when the number of items on the agenda increased. The developed countries have argued that all countries should adopt strong IPRs, claiming they are in the interests of the developing countries themselves. If that is the case, then they should be presented with evidence that this is so, and presumably, if the evidence is as overwhelming as the United States claims, countries will voluntarily undertake these standards. In fact, the agenda that the United States Trade Representative has pushed is not designed to benefit developing countries, to maximize their growth or the well-being of the people living there; it is designed to maximize the transfer of rents from others to the United States and to maximize the rents enjoyed by certain sectors within the United States. The United States is right in emphasizing the importance of intellectual property rights, but it is only one part of a country's innovation system, and it has to be carefully designed if it is to promote development and societal well-being.

China should be wary about borrowing economic or legal frameworks from others in any arena, but especially so in intellectual property, where almost surely the standards that are appropriate for advanced industrial countries are different from those appropriate to developing countries, and in which special interests have played such a large role in determining the standards elsewhere. It would not be in the interests of developing countries in general and China in particular to adopt standards that reflect, say, the balancing between static efficiency and 
dynamic gains (or among various political forces) in the US. China needs to remember that the US IPR regime reflects the influence of particular interest groups, not a well-considered balancing of static and dynamic, efficiency, and equity trade-offs.

\section{IPR AND NATIONAL INNOVATION SYSTEMS: GLOBAL PERSPECTIVES}

Most of this paper focuses on the design of China's innovation system, and in particular on its IPR regime, which inevitably will be viewed within the context of IPR regimes being adopted around the world. As China's influence in the global economy increases, it will be important for it to fight for a global IPR regime that supports its own interests. But it should simultaneously fight for a global IPR regime that is consistent with the interests of other developing countries. The previous section argued for a global regime that allows developing countries to design their own IPR regimes. This section elaborates on what an appropriate global IPR entails. Our discussion focuses on the implications of the fact that knowledge is a global public good, as well as on global institutional arrangements.

\section{Financing knowledge as a global public good}

We know that knowledge is a global public good. If we were to ask what is a fair and efficient way of financing such a global public good, standard principles of public finance would suggest that the costs be borne by those most able to bear them, and that the market not be distorted by imposing prices in excess of marginal costs. For those in the advanced industrial countries to bear the burden of financing basic research may be a highly effective way of providing foreign assistance to the poorest countries of the world.

Under current arrangements, American taxpayers providing foreign assistance for health in developing countries indirectly are providing funds that go to American drug companies, as the health care budgets of the developing countries pay a "research tax" in the form of a price in excess of marginal costs. And taxpayers in developing countries supporting their countries' health budgets are also helping to finance American drug companies. Thus, the patent system is not only distortionary, but also inequitable, with transfers from the poor countries to the rich, an inequitable system of funding research.

\section{TRIPS and intellectual property rights}

There is a broad consensus among academic economists-including some who are strongly in favor of multilateral agreements liberalizing trade between developed and less developed countries-that intellectual property should never have been included in trade negotiations. ${ }^{34}$ The World Trade Organization is 
supposed to promote trade; many of the provisions associated with enforcing IPR entail restrictions on trade. Unlike traditional trade liberalizations, where tariff reductions benefit both the exporter and the importer, intellectual property rights represent a transfer; the holder of the intellectual property right is better off and the user is worse off. To be sure, advocates of intellectual property rights try to claim that in the long run everyone is better off, but such claims are hard to substantiate, especially when the IPR regime is unbalanced and not well designed.

Most importantly, the parties involved in negotiations at the WTO are trade ministers who are not well suited to engage in the careful balancing that is required if we are to have well-designed intellectual property rights. As noted, this was evident during the Uruguay Round, when the concerns of developing countries, the scientific community, and health advocates were given short shrift in favor of the interests of America's pharmaceutical and media industries. Nowhere were the problems with TRIPS more evident that in the treatment of lifesaving drugs. The original text contained ambiguities - the developing countries thought that they had the right to force compulsory licensing for lifesaving drugs that otherwise would not be affordable. The United States thought otherwise. Eventually, a world outcry forced the drug companies to step back, and in Doha, there was an agreement that this was to be one of the issues to be addressed. But just a month before the meeting in Cancun, the United States still was reluctant to go very far. The key question was whether a small country facing an AIDS epidemic, such as Botswana, could purchase from South Africa generic drugs that it was too small to produce itself. Would it have to pay the high American prices? Or could it import lower-priced drugs produced under compulsory licenses from South Africa? While the United States eventually gave in to the global consensus, the dispute made clear the nature of the disagreements about the appropriate framework for intellectual property rights. Clearly, in this case, the position taken by the United States was not "developmentally oriented." But the eventual agreement still fell far short of a minimal developmentally oriented agreement because the United States continued to insist that access be given only in the case of an epidemic. It is, and should be, a concern to developing countries that their citizens are dying needlessly because they cannot get access to lifesaving drugs at affordable prices, whether there is an epidemic or not. It is certainly a legitimate position for developing countries to insist on compulsory licensing for lifesaving medicines when monopoly pricing on the part of the patent holder leaves prices at levels substantially above the costs of production. That developing countries could not get American acquiescence on this fundamental principle even in a round of trade negotiations that was called the "Development Round" suggests that such matters need to be taken out of the WTO and put into other venues.

Even from the outset, it was recognized that the TRIPS agreement was unbalanced, with costs imposed on developing countries almost surely greater than the benefits and with intellectual property protection concerns of developing countries being given short shrift. While developing countries would have to pay more for drugs, the drug companies invested little in the diseases afflicting poor people, especially those in developing countries. There was little protection afforded to the traditional knowledge of developing countries, and drug companies' oppositions to paying for the value of the knowledge associated with the genetic material obtained from developing countries led to the refusal of the United States and 
other advanced industrial countries to sign the Convention on Biological Diversity.

\section{Access to health}

In 2003, the international Commission on the Social Dimensions of Globalization, recognizing the severe potential adverse impact of TRIPS on health conditions in developing countries and how lack of access to knowledge could impair their development, called for a rethinking of TRIPS. ${ }^{35}$ The problems were rightly anticipated to worsen as developing countries rewrote their intellectual property laws to conform to TRIPS. Producers of generic drugs still covered by patents in their countries of origin, so critical to the provision of low-cost medicines in developing countries, might be forced out of business. Meanwhile, there were worries that even the "flexibilities" built into the Uruguay Round agreement (supposedly to allow countries to balance other concerns, such as access to health) would be undermined, as the US and Europe might subtly threaten developing countries that exercised their rights to issue compulsory licenses, even when the country is complying with all the rules of TRIPS - and there are a variety of actions that the developed countries can undertake against any developing country going against the wishes of the advanced industrial countries that are very costly to the developing countries. ${ }^{36}$ So, it is not just how the rules were designed, but also the ways in which they are being implemented that has made it more difficult to get access to these generic medicines. All of these fears and worries have proven justified. $^{37}$

If the WTO really were interested in making sure people have access to generic medicines, the set of procedures would look very different. There might, for instance, be a list of lifesaving drugs, or drugs that address debilitating disease, which any generic producer could sell in any country whose income was below a critical threshold. Even better would be the reverse presumption: any generic producer could sell any drug in any country whose income was below a critical threshold, unless the owner of the patent substantiated that it was a lifestyle drug, of little value in addressing either life-threatening or debilitating diseases.

Rather than the rebalancing of intellectual property regimes (toward something called TRIPS minus) that the Commission on the Human Dimensions of Globalization called for, these obligations have been extended as part of bilateral agreements; these regimes have been dubbed TRIPS plus. So far, these have embraced a relatively small fraction of global trade. Still, it is very disturbing that so many of them require developing countries to agree to an intellectual property regime that is even more unbalanced than TRIPS, that restricts further, for instance, access to generic drugs. ${ }^{38}$ For these countries, the globalization of intellectual property has had severe consequences: increasing havoc in their public health systems, draining royalties toward rich countries, undermining the availability of resources available to address other health or developmental needs, and decreasing access to health. ${ }^{39}$

The examples provided illustrate the gulf in interests between the advanced industrial countries and the developing and emerging markets with respect to IPR. The IPR regime that has emerged globally largely reflects the interests and 
perspectives of the former-and the special interests within them. There is a need to give greater voice to the concerns of the developing world. This is a matter of both efficiency and equity. Unless this is done, there is the prospect of an everincreasing gulf between the developed and less developed worlds.

Giving emerging markets and developing countries more voice in the design of their intellectual property regimes will not suffice. They will also need financial assistance. Resources are required to design and implement an intellectual property regime. As in other areas of the law, access to the benefits that might be provided requires resources; given the disparity in access to resources, even a seemingly fair IPR regime may lead to unfair outcomes. Earlier, we discussed how the intellectual property regime could, de facto, serve as an entry barrier, discriminating in practice against small firms. The same logic applies internationally. We have already alluded to some of the resulting inequities. It is not just that the legal framework formally does not give adequate recognition to traditional knowledge; it may also be difficult for a developing country to challenge a patent on traditional knowledge. If the international community is really committed to a development-oriented IPR agenda, it will have to recognize:

(i) The importance of the need for impartial technical assistance;

(ii) The need for financial assistance in creating an appropriate IPR regime within each country;

(iii) And legal assistance (financial and technical) to challenge patent applications and to obtain patents in more advanced industrial countries. Without such assistance, there cannot be fairness and there is a risk that whatever the legal framework, the interests of the developing countries will be given short shrift.

This will go only part of the way toward achieving a level playing field. The advanced industrial countries have a number of ways in which they can apply pressure to developing countries. They can threaten to cut off foreign aid or restrict preferential trade access; the international economic institutions too can try to force more stringent intellectual property regimes as a condition for assistance. In some cases, simple pressure may work without the threat of explicit sanctions. For instance, developing countries are told-and sometimes believethat without strong IPR regimes, foreign investment will not come. The fact that there has been so much foreign investment in China, in spite of allegations of inadequate IPR protection, is evidence to the contrary.

A more balanced intellectual property regime, one which reflects the concerns within developing countries and that gives them more scope for pursuing a developmentally oriented intellectual property regime-as part of a broader developmentally oriented innovation system-is in the interests of the world. It would facilitate the closing of the gap between the haves and the have-nots. A balanced regime is required, moreover, if the kinds of aspirations that were articulated in the Millennium Development Goals are to be achieved. 


\section{CONCLUDING REMARKS}

Intellectual property is important, but is only one part of a country's innovation system. This paper has discussed several critical features relevant to the creation of an innovation system - including intellectual property rights—designed to enable China to continue its remarkable success, including its ability to achieve its ambition to become an innovation economy and its broader social goals of harmonious growth, including the reduction of inequality and protection of the environment.

The IPR regime that has come to dominate in much of the world is not even well designed for the broader interests of the advanced industrial countries from which it emanates; rather, it is largely designed to maximize the profits of a few sectors that derive their returns largely from intellectual property rights. Not surprisingly, such an intellectual property regime is not in the interests of China. Different countries, facing different circumstances, need to design intellectual property regimes that are appropriate to their circumstances. China's circumstances are distinctive, and so it will have to look for an innovation system and an IPR regime that is correspondingly distinctive-an intellectual property regime "with Chinese characteristics." For instance, given the importance that should be placed on innovation to protect the environment, an arena in which market prices do not reflect social values, there needs to be even less reliance on market-induced innovation (supported by the IPR regime) and greater reliance on public funding.

China is still at a stage in its transition to a market economy where those with vested interests in a flawed IPR system do not play the role that they do in the US. Nor are the flawed ideological presumptions that have played such a central role in shaping America's IPR system as influential. China, at this stage in its transition, has the opportunity to learn from the mistakes of the advanced industrial countries. It should, for instance, take the portfolio approach stressed in this paper, with greater emphasis on a prize system and less on the patent system.

Designing an intellectual property regime (and more broadly, an innovation system) appropriate for China is not an easy task, especially since so much depends on details. We have seen how a poorly designed intellectual property regime may (i) impair static efficiency, both through the creation of impediments to the usage of knowledge and enhancing monopoly power; (ii) lower the pace of innovation and growth; (iii) distort the allocation of resources to research; (iv) lead to inefficiently high expenditures on litigation; (v) lead to a less healthy population; (vi) while simultaneously increasing public expenditures on health.

In the aftermath of the Great Recession, there has been a change in the global economic balance of power. China will play an increasing role in shaping the global economic regime. As part of that role, it needs to help create a global intellectual property regime that is more development-oriented, more flexible, more sensitive to the differing circumstances confronting different countries.

China is an emerging market economy, better off than the least-developed countries, not as well off as the advanced industrial countries. In other arenas, it has become an effective advocate for the interests of the less developed countries. It should do so in this area as well, arguing for an intellectual property regime that is globally fair and efficient. It can do so more effectively if it adopts an intellectual property regime consistent with these principles. 
Doing so will be important for the world, and especially for other developing countries. But doing so is also important for China itself.

\section{NOTES}

1. This chapter is a revised and adapted version of a keynote address presented at the Ministerial Conference on Intellectual Property for Least Developed Countries, World Intellectual Property Organization (WIPO), Seoul, October 25, 2004, and of a talk titled "Institutional Design For China's Innovation System: Implications For Intellectual Property Rights," Beijing University, March, 2007. This chapter also draws heavily upon chapter 4 of Stiglitz $(2006,2008)$ and Henry and Stigliz (2010). Many of the ideas discussed here are developed further in Cimoli et al. (forthcoming). I am indebted to Jamie Love for discussions and comments, to Francesco Brindisi for research assistantship, and to the Ford, MacArthur, and Mott Foundations for financial support.

2. In 2010, per capita GDP in China was US\$4,382 (PPP \$7,519), compared to $\$ 47,284$ per capita in the US.

3. This was one of the central messages of Stiglitz (2002a).

4. Statement by Brazil on September 30, 2004 before WIPO General Assembly at the introduction of the proposal for a development agenda.

5. The patents on basmati rice and the medicinal uses of turmeric were eventually overthrown, but the costs of litigation were significant (see Stiglitz 2006 and Brand 2005). Indeed, even the US courts have recognized these costs. In United States $v$. General Electric Co., 115 F. Supp. 835, 844 (1953) the court, in arguing for compulsory licensing with zero royalties, noted that "small firms desiring to stay in or gain a foothold in the industry... may well be unequipped to engage in litigation on the validity of one patent after another at what could be incalculable expense. In order to avoid it they could be required to shoulder royalties which could prove to be the very factor that would push them out of the competitive circle of the market" (cited in Love 2004). See Stiglitz (2006) and Perleman (2002).

6. See, e.g., Coase (1960).

7. Though the concept of a public good is intuitive, it was first formalized by Samuelson (1954) as a good for which the marginal cost of an additional individual using the good is zero (referred to as nonrivalrous consumption) and for which the cost of excluding someone from usage was high (nonexclusivity). The view of knowledge as a public good is discussed in Stiglitz (1987).

8. Jefferson described the public good characteristics of knowledge in the following way: "... no one possesses the less because everyone possesses the whole of it. He who receives an idea from me receives [it] without lessening [me], as he who lights his [candle] at mine receives light without darkening me" (quoted in Meier 1981).

9. A global public good is one whose benefits can extend to everyone in the world (as opposed to a local public good, the benefits of which accrue only to those in a particular locality, or a natonal public good, the benefits of which occur only to those within a country) (see Stiglitz 1995). The idea that knowledge is a global public good is developed in Stiglitz (1999).

10. See Dasgupta and Stiglitz (1980) and Gilbert and Newbery (1982).

11. See e.g., Dasgupta and Stiglitz (1988); Fudenberg et al. (1983); and Farrell, Gilbert, and Katz (2003). 
12. In practice, there is usually some value to a me-too innovation-for instance, there may be some patients for whom the side effects are less-but still, the social return to such innovations is very limited and less than the private returns.

13. See Arrow (1962). One of the reasons is that monopoly reduces the scale of production, and at a reduced scale of production, the benefits of, say, cost reductions are smaller.

14. Microsoft was able to leverage its monopoly power in operating systems (protected by intellectual property rights) to squelch innovators in browsers and media players. Potential innovators, knowing this, have less incentive to innovate. See Stiglitz (2006).

15. If the owner of IPR could engage in perfect price discrimination, he would always charge the highest royalty that would still induce innovation. Such perfect price discrimination is not feasible, and with imperfect price discrimination, the licensing fees that would be optimal will be so high as to discourage some of those in developing countries from adapting the technology to their economy or some of those who might otherwise undertake follow-on research from doing so. Moreover, even with perfect discrimination, the high royalties will have an adverse effect on development, simply because of the large transfers.

16. See for instance "Public Comment on the Unites States Patent and Trademark Office N.41," 03/22/2000 by Bruce Alberts, president of the National Academy of Science, available at <http://www.uspto.gov/web/offices/com/sol/comments/utilguide/nas.pdf > (accessed on October 12, 2011).

17. See Boyle (2003).

18. He in fact used his patent to try to organize an automobile cartel. Had the patent not been challenged by Henry Ford, who wanted to create a low-priced car, the development of the automobile would have been greatly impeded. For a discussion of this and other problems with the patent system, see Stiglitz (2006).

19. There is even a reluctance to share data.

20. For example, a very broad automobile patent would extend to any self-propelled vehicle, a narrow patent to the specific kind of car that was constructed.

21. The discussion of this section is adapted from Stiglitz (2008).

22. See Henry and Stiglitz (2010).

23. In 2009, Medicare and Medicaid spending were $\$ 502.3$ billion and $\$ 373.9$ billion respectively, which consists of 20 percent and 15 percent respectively of the total national health care spending.

24. I say "excessive" because it may in fact be optimal to have several independent, parallel research efforts.

25. The evidence is that capital markets do not fully spread risks faced by firms, because of imperfections of information. See for example Greenwald and Stiglitz (1990), who discuss the effect of information imperfections on firm behavior and argue that informational problems in the capital market cause firms to act in a risk-averse manner. There is also considerable empirical evidence that markets do not efficiently distribute risk, i.e., firms act in a risk-averse manner, even when risks are uncorrelated with the market. See, e.g., Stiglitz (1982).

26. For instance, in the case of "orphan drugs," the life of the patent was extended, because it was thought that the benefits from greater incentives to innovate exceeded the costs. A still better way of creating incentives for such innovation, however, could have been provided through the prize system.

27. India was right, I think, in its recent decision concerning Novartis's attempt to evergreen its patent. In June 2009, India's Intellectual Property Appellate Board ruled 
that Novartis's patent on the cancer drug Glivec is not valid in that country; it marks the third time in four years that Novartis has failed in attempts to claim patent on its best-selling cancer drug. Concurring with earlier decisions, the board ruled that Glivec is nothing but a crystal modification of an older drug that was initially patented in 1993 and therefore does not qualify as a new invention. Under patenting rules that India began implementing in 2005, only drugs invented after 1995 are eligible for patent protection.

28. The suit, The Association for Molecular Pathology et al., v. United States Patent and Trademark Office, et al., had at the time of writing been decided favorably for the defendants—of which Myriad is one-holding that companies can obtain patents for genes. In April 2010, the US District Court for the Southern District of New York invalidated patents on a pair of genes linked to breast and ovarian cancer held by Myriad. See Stiglitz (2010). But in July 2011, the Court of Appeals for the Federal Circuit overturned this decision (Pollack 2011). A further appeal in September 2011 was denied (dismissal may be viewed at $<\mathrm{http}$ ://www.genomicslawreport.com/wpcontent/uploads/2011/09/Myriad-Dispositions.pdf $>$, accessed on October 12, 2011); the Supreme Court is the remaining avenue of appeal.

29. See Brunswick, 36 Fed. Cl. at 207; cited in Love (2004: 13). Since the government already possesses the right, exercising the right is not a "taking" requiring compensation.

30. United States v. W. Elec. Co., 1956 Trade Cas. (CCH) 68,246, at 71,139 (D.N.J. 1956).

31. Under a US law called the Tunney Act (Antitrust Procedures and Penalties Act, 15 U.S.C. \$16), members of the public have an opportunity to comment on a proposed settlement of a civil antitrust suit before it is accepted by a court. At the time of the proposed Microsoft settlement, I filed an affidavit together with Jason Furman (later the Deputy Head of the US National Economic Council) explaining why limiting the length of the patent would be a preferable way for addressing the anticompetitive abuses. See Stiglitz (2002b).

32. See, e.g., Reichman and Lewis (2005) and Shapiro (2007).

33. See Charlton and Stiglitz $(2004,2005)$.

34. See Bhagwati $(2002,2004)$.

35. See World Commission on the Social Dimensions of Globalization (2004).

36. They can, for instance, withdraw preferential trade provisions or not support bilateral or multilateral assistance packages.

37. Critics of India's new intellectual property law argue that it went beyond what was required by the TRIPS agreement. Court decisions, e.g., against Novartis's attempt to "evergreen" its patents have maintained some balance.

38. The provisions on data exclusivity that have been included in many of the bilateral trade agreements that the United States has signed have also exacerbated the problem of access to generic medicines. Even if a compulsory license is issued, there is an attempt to restrict the use of data that might be required to establish the safety and efficacy of the generic drug. Although there are changes to the regulatory structures that might allow developing countries to circumvent the restrictive impact, e.g., simply by requiring generic producers to show the bio-equivalence of their product to products that have been shown to be safe and efficacious in the US or Europe, developing countries appear to be under pressure not to make the necessary regulatory changes.

39. See World Bank (2001). 


\section{REFERENCES}

Alberts, B. (2000), "Public Comment on the United States Patent and Trademark Office N.41," March 22 (Washington, DC: National Academy of Sciences).

Arjun, J. and Stiglitz, J. E. (2009), “Two Ideas to Increase Innovation and Reduce Pharmaceutical Costs and Prices," Health Affairs, 28/1: 165-8.

(2010), "Medicine for Tomorrow: Some Alternative Proposals to Promote Socially Beneficial Research and Development in Pharmaceuticals," Journal of Generic Medicine, 7/3: 217-26.

Arrow, K. J. (1962), "Economic Welfare and the Allocation of Resource for Invention," in R. Nelson (ed.), The Rate and Direction of Inventive Activity: Economic and Social Factors (Princeton: Princeton University Press for the NBER), 609-25.

Bhagwati, J. (2002), "Afterword: The Question of Linkage," The American Journal of International Law, 96/1: 126-34. (2004), In Defense of Globalization (New York: Oxford University Press).

Boyle, J. (2003), “The Second Enclosure Movement and the Construction of the Public Domain," Law and Contemporary Problems, 66/33: 33-74.

Brand, R. (2005), "The Basmati Patent," in E. U. von Weizäcker, O. R. Young, and M. Finger (eds), Limits to Privatization: How to Avoid Too Much of a Good Thing (London: Earthscan Publications).

Charlton, A. and Stiglitz, J. E. (2004), The Development Round of Trade Negotiations in the Aftermath of Cancun, prepared for the Commonwealth Secretariat, the Initiative for Policy Dialogue (New York: Columbia University).

(2005), Fair Trade for All (New York: Oxford University Press). Published in Simplified Chinese by China Renmin University Press.

Cimoli, M., Dolsi, G., Maskus, K., Okediji, R., and Reichman, J. (forthcoming), Intellectual Property Rights: Legal and Economic Challenges for Development, IPD Book Series (New York: Oxford University Press).

Coase, R. H. (1960), "The Problem of Social Cost," Journal of Law and Economics, 3 (October): 1-44.

Dasgupta, P. and Stiglitz, J. E. (1980), "Uncertainty, Market Structure and the Speed of R \& D,” Bell Journal of Economics, 11/1: 1-28.

(1988), "Potential Competition, Actual Competition and Economic Welfare," European Economic Review, 32 (May): 569-77.

Farrell, J., Gilbert, R. J., and Katz, M. L. (2003), "Market Structure, Organizational Structure, and R \& D Diversity," in R. Arnott, B. Greenwald, R. Kanbur, and B. Nalebuff (eds), Economics for an Imperfect World-Essays in Honor of Joseph E. Stiglitz (Cambridge, MA: MIT Press).

Fudenberg, D., Gilbert, R., Stiglitz, J. E., and Tirole, J. (1983), "Preemption, Leapfrogging and Competition in Patent Races," European Economic Review, 22: 3-32.

Gilbert, R. J. and Newbery, D. M. G. (1982), "Preemptive Patenting and the Persistence of Monopoly," American Economic Review, 72/3: 514-26.

Greenwald, B. and Stiglitz, J. E. (1990), “Asymmetric Information and the New Theory of the Firm: Financial Constraints and Risk Behavior," American Economic Review, 80/2: 160-5. Also NBER Working Paper No. 3359.

Henry, C. and Stiglitz, J. E. (2010), "Intellectual Property, Dissemination of Innovation and Sustainable Development," Global Policy, 1: 237-51.

Jayadev, A. and Stiglitz, J. E. (2009), "Two Ideas to Increase Innovation and Reduce Pharmaceutical Costs and Prices," Health Affairs, 28/1: 165-168.

(2010), "Medicine for Tomorrow: Some Alternative Proposals to Promote Socially Beneficial Research and Development in Pharmaceuticals," Journal of Generic Medicines, 7/3: 217-26. 
Love, J. (2004), “Compensation Guidelines for Non-Voluntary use of a Patent on Medical Technologies." Mimeo, September 7.

Meier, H. A. (1981), "Thomas Jefferson and a Democratic Technology," in C. W. Pursell (ed.), Technology in America: A History of Individuals and Ideas, 2nd edition (Cambridge, MA: MIT Press).

Perleman, M. (2002), Steal this Idea: Intellectual Property and the Corporate Confiscation of Creativity (New York: Palgrave).

Pollack, A. (2011), "Ruling Upholds Gene Patent in Cancer Test," The New York Times, July 29, available at <http://www.nytimes.com/2011/07/30/business/gene-patent-incancer-test-upheld-by-appeals-panel.html?_r $=1 \& \mathrm{scp}=1 \& \mathrm{sq}=$ ruling\%20upholds\% 20gene\%20patent\%20in\%20cancer\%20test\&st = cse > (accessed October 12, 2011).

Reichman, J. H. and Lewis, T. (2005), "Using Liability Rules to Stimulate Local Innovation in Developing Countries: Application to Traditional Knowledge," in Keith E. Maskus and J. H. Reichman (eds), International Public Goods and Transfer of Technology under a Globalized Intellectual Property Regime (Cambridge: Cambridge University Press).

Samuelson, P. A. (1954), "The Pure Theory of Public Expenditure," Review of Economics and Statistics, 36/4: 387-89.

Shapiro, C. (2007), "Patent Reform: Aligning Reward and Contribution 33-35," Working Paper No. 13141 (Cambridge, MA: National Bureau of Economic Research), available at $<$ http://papers.nber.org/papers/w13141> (accessed October 12, 2011).

Stiglitz, J. E. (1982), "Ownership, Control and Efficient Markets: Some Paradoxes in the Theory of Capital Markets," in K. D. Boyer and W. G. Shepherd (eds), Economic Regulation: Essays in Honor of James R. Nelson (East Lansing: Michigan State University Press).

- (1987), "On the Microeconomics of Technical Progress," in J. M. Katz (ed.), Technology Generation in Latin American Manufacturing Industries (New York: Macmillan Press). (Presented to IDB-Cepal Meetings, Buenos Aires, November 1978.)

- (1988), "Technological Change, Sunk Costs and Competition," Brookings Papers on Economic Activity, 18/3: 883-947.

- (1995), "The Theory of International Public Goods and the Architecture of International Organizations," Background Paper No. 7, Third Meeting, High-Level Group on Development Strategy and Management of the Market Economy, UNU/WIDER, Helsinki, Finland, July 8-10.

(1999), "Knowledge as a Global Public Good," in I. Kaul, I. Grunberg, and M. A. Stern (eds), Global Public Goods: International Cooperation in the 21st Century, United Nations Development Programme (New York: Oxford University Press).

(2002a), Globalization and its Discontents (New York: W. W. Norton).

- (2002b), Declaration of Joseph E. Stiglitz and Jason Furman, United States v. Microsoft Corp., 97 F. Supp. 2d 59 (D.D.C. 2000) (Nos. 98-1232, 98-1233), available at <http:// usdoj.gov/atr/cases/ms_tuncom/major/mtc-00030610c.pdf>. (2006), Making Globalization Work (New York: W. W. Norton).

- (2008), "The Economic Foundations of Intellectual Property," Sixth Annual Frey Lecture in Intellectual Property, Duke University, Durham, NC; Duke Law Journal, 57/6 (February 16): 1693-724.

- (2010), "Declaration of Joseph Stiglitz," Amicus filing, Case 1:09-cv-04515-RWS Document 224 Filed 01/20/2010.

World Bank (2001), Global Economic Prospects and the Developing Countries: Making Trade Work for the World's Poor (Washington, DC: World Bank).

World Commission on the Social Dimensions of Globalization (2004), A Fair Globalization: Creating Opportunities for All (Geneva: World Commission on the Social Dimension of Globalization), available at <http://www.ilo.org/public/english/wcsdg/docs/ report.pdf $>$. 